\title{
Dehanding in Improving Fruit Quality of Banana
}

\author{
S. Sarkar \\ Dept. of Fruits and Orchard Management, BCKV, Mohanpur, Nadia West Bengal (741 252), India \\ Presently Cooch Behar Krishi Vigyan Kendra, UBKV, Pundibari, Cooch Behar, West Bengal (736 165), India
}

\section{Article History}

Manuscript No. AR741a

Received in $4^{\text {th }}$ May, 2014

Received in revised form $18^{\text {th }}$ March, 2015

Accepted in final form $25^{\text {th }}$ March, 2015

\section{Correspondence to}

E-mail: drsurajitskr@gmail.com

\section{Keywords}

Banana, dehanding, principal component analysis, quality, yield

\begin{abstract}
The experiment was conducted at the Horticultural Research Station, Mondouri, Bidhan Chandra Krishi Viswavidyalaya, West Bengal, India during the years 2007-2010 to assess the effect of dehanding on physico-chemical properties and quality of banana (Musa AAA Cv. Grande Naine). Accordingly terminal/distal hand (s) were removed in 3 (three) different intensity viz., i) removal of 1 (one) hand, ii) removal of 2 (two) hands and iii) removal of 3 (three) hands at various time after bunch emergence i.e, i) immediately after opening of last hand, ii) one week after opening of last hand, iii) two weeks after opening of last hand and iv) three weeks after opening of last hand. In general, dehanding decreased bunch weight over control and the intensity of reduction increased with delayed dehanding after opening of last hand. But removal of three hands immediately after opening of last hand increased fruit weight, fruit length, fruit circumference and pulp weight to the maximum tune of 53.9, 34.5, 13.9 and $58.6 \%$ respectively over the control. Unlike fruit morphological characters, the biochemical composition of fruits was not influenced significantly by dehanding except with reducing sugar. Dehanding also shortened the crop cycle by 18 days. The results signified the relevance of dehanding in improving market appeal and customer attraction of banana.
\end{abstract}

\section{Introduction}

Within bunch variability in banana finger size is of great importance. In general, the last hands are discarded or sold at lower prices because they fail to meet the standard of specialized markets. Fingers of the distal hand (at the bottom of bunch) are $30-40 \%$ smaller than proximal fingers at the top of the bunch. This negative gradient in fruit weight and size is related to a difference in developmental stage between proximal fruits and distal fruits. For the fingers located at the proximal hand, cell division ceases at around 350 degree day whereas cell division start and stop approximately 70 degree day later in bottom distal hands compared to the top proximal hand fingers (Jullien et al., 2001a). Due to competition for assimilate, pulp cell number is reduced in younger fruits of distal hands, which ultimately become determining factor in decreasing pulp dry weight in distal hands (Jullien et al., 2001b).

Internal limitations to fruit growth due to competition for photo-assimilates within the plant are well known (Dennis, 1982). Once a threshold number is reached, further increases in fruit number per plant reduce fruit size (Krauss et al., 1999). Rodriguez et al. (1988) noted that the distal hands which do not reach commercial size, constitute a loss in respiration and represent a redistribution of dry matter which is of no or little commercial use. When such hands are severed, dry matter would be redistributed among the remaining hands in the bunch, thereby increasing finger size. So the current study was undertaken to grow better quality of banana fruit by adopting some alteration in management practice for catering need of specialized market as well as ensuring food security (Huda et al., 2011.)

\section{Materials and Methods}

The study was carried out thrice at the Horticultural Research Station, Mondouri, Bidhan Chandra Krishi Viswavidyalaya, Mohanpur, Nadia, West Bengal, India during the years 2007-08, 2008-09 and 2009-10 and pooled data were used for analysis. Banana (Musa AAA) Cv. Grande Naine was used for the study having the treatments of terminal/distal hand(s) removal in 3 (three) different intensity viz., i) removal of 1 (one) hand $\left(\mathrm{H}_{1}\right)$, ii) removal of 2 (two) hands $\left(\mathrm{H}_{2}\right)$ and iii) removal of 3 (three) hands $\left(\mathrm{H}_{3}\right)$ at various time after bunch emergence i.e, i) immediately after opening of last hand $\left(R_{1}\right)$, ii) one week after opening of last hand $\left(\mathrm{R}_{2}\right)$, iii) two weeks after opening 
of last hand $\left(\mathrm{R}_{3}\right)$ and iv) three weeks after opening of last hand $\left(\mathrm{R}_{4}\right)$. The experiment was laid out in augmented 2-factor factorial CRD followed by principal component analysis (PCA) based on correlation matrix for all the characters to extract performing treatment (s) due to specific set of character (s)/ parameter (s). Bunches having eight hands were considered for the treatments and male bud was removed keeping 8-10 $\mathrm{cm}$ after the last hand.

Observations were recorded with respect to bunch weight, finger weight, finger length, finger circumference, finger volume, finger density, pulp and peel weight, pulp to peel ratio, peel and pulp thickness, shooting-harvest interval, harvest index, total soluble solids, total, reducing and non-reducing sugar and ascorbic acid content. The physico-chemical properties were measured from the ' $\mathrm{D}$ ' finger, i.e. middle finger in top/upper row of second hand (Gottreich et al., 1964).

\section{Results and Discussion}

Table 1 revealed that interaction between number of hand removal and time of hand removal revealed that the treatments excluding removal of one hand irrespective of its time and removal of two hands after one week of opening of last hand significantly decreased bunch weight. Removal of three hands immediately after opening of last hand produced about 58\% more fruit weight $(174.08 \mathrm{~g})$ than control. Finger size was also significantly increased by removal of three hands immediately after opening of last hand $\left(\mathrm{H}_{3} \mathrm{R}_{1}\right)$ and the increase in finger length and circumference was 35 and $12 \%$, respectively as compared to control (non removal of hand). Removal of terminal hand (s) did not increase average yield but improved both size and weight of fingers. Similar results have been obtained by Quintero and Aristizabal (2003), Weerasinghe and Ruwanpathirana (2004); Wanichkul and Boonma (2009) in different Musa cultivars in tropics and semi-tropics. Aba et al. (2009) and Baiyeri et al. (2010) in 'PITA 24 hybrid. However in the work of Kurien et al. (2000), removal of false hand and one or two of the smallest apical hands improved the yield and also grade of the fruit. In the present study finger size and weight were better because the terminal hands might act as more efficient sinks drawing more nutrients. So, pruning of terminal hand attributed to the reduction in available sink size; thereby concentrating assimilates in a smaller sink volume (Baiyeri et al., 2009), assuring the assimilates are not wasted on under graded fingers at the distal end of the bunch but channeled for the optimum growth of the remaining fruits.

Better finger size, finger weight and bunch weight were obtained when dehanding was done immediately after opening of last hand which gradually decreased with the advancement of interval in day from opening of last hand (Table 1). Hand removal after 3 weeks of opening of last hand caused drastic reduction in fruit size, fruit weight and bunch weight. This reduction might be attributed due to completion of cell division within 3 (three) weeks after emergence of hand and fruit growth progresses mainly by cell enlargement. Pruning during cell division phase seems to have a positive effect on ultimate fruit size, as delayed pruning (i.e. during cell enlargement) would amount to loss of accumulated food reserve. Fruit growth by cell division and enlargement on the proximal hands (which are first to be initiated on the bunch meristems) is in advanced stage compared with fruits on the distal extremities (Jullien et al., 2001b).

Removal of hand(s) at different times reduced shooting-harvest interval from 5 to 18 days (Table 1). Maximum reduction of shooting-harvest interval was recorded with removal of three hands immediately after opening of last hand $\left(\mathrm{H}_{3} \mathrm{R}_{1}\right)$. Regarding harvest index, removal of two and three hands after two weeks of opening of last hand significantly reduced harvest index (Table 1). Reduction in shooting-harvest interval might be happened due to increase in cell filling rate due to hand removal, which was in conformity with the work of Jullien et al. (2001b) in cv. Grande Naine.

Among the bio-chemical properties, reducing sugar was increased significantly over control (Table 1), which might be due to increased rate of fruit filling in the fruits of the dehanded bunch. However, the variation in the time of removal of hand(s) did not produce any significant change in total soluble solids (TSS), total sugar, non-reducing sugar and ascorbic acid content of ripe finger in comparison with control of non removal of hand (Table 1).

Among the interactions between the intensity and time of hand removal, removal of one hand immediately after opening of last hand $\left(\mathrm{H}_{1} \mathrm{R}_{1}\right)$ significantly produced highest benefit/cost ratio of 2.672 followed by removal of one hand after one week of opening of last hand $\left(\mathrm{H}_{1} \mathrm{R}_{2}\right)$ and removal of one hand after two weeks of opening of last hand $\left(\mathrm{H}_{1} \mathrm{R}_{3}\right)$ which were statistically at par with $H_{1} R_{1}$. Whereas, removal of three hands after three weeks of opening of last hand $\left(\mathrm{H}_{3} \mathrm{R}_{4}\right)$ proved to be least cost effective. Delayed hand pruning reduced the yield considerably thereby decreasing the benefit cost ratio. Baiyeri et al. (2010) also found in their study on plantain 'PITA- 24' (Musa AAB) that bunch pruning management at later stage of opening of last female hand could not give optimum results.

In order to compare the performance of varying combination of treatments due to number of hand removal $(\mathrm{H})$ and time of hand removal (R) on the basis of different parameters principal component analysis (PCA) was followed and factors having Eigen value more than one and explaining at least $5 \%$ of total variance were considered. Thus four (4) factors were derived explaining over $91 \%$ of total variance.

Finger weight, finger length, finger circumference, TSS, total sugar, reducing sugar and ascorbic acid dominated factor 1 


\begin{tabular}{|c|c|c|c|c|c|c|c|c|c|c|c|c|}
\hline $\begin{array}{l}\text { Treat- } \\
\text { ment }\end{array}$ & $\begin{array}{c}\text { Bunch } \\
\text { weight } \\
\text { (kg) }\end{array}$ & $\begin{array}{c}\text { Finger } \\
\text { weight } \\
(\mathrm{g})\end{array}$ & $\begin{array}{c}\text { Finger } \\
\text { length } \\
(\mathrm{cm})\end{array}$ & $\begin{array}{c}\text { Finger } \\
\text { circumfer- } \\
\text { ence }(\mathrm{cm})\end{array}$ & $\begin{array}{l}\text { Pulp } \\
\text { weight } \\
\text { (g) }\end{array}$ & $\begin{array}{c}\text { Shooting- } \\
\text { harvest } \\
\text { (day) }\end{array}$ & $\begin{array}{l}\text { Benefit } \\
\text {-Cost } \\
\text { ratio } \\
\end{array}$ & $\begin{array}{c}\text { TSS } \\
\text { ( }{ }^{\circ} \text { brix) }\end{array}$ & $\begin{array}{c}\text { Total } \\
\text { sugar } \\
(\%) \\
\end{array}$ & $\begin{array}{l}\text { Reduc- } \\
\text { ing sugar } \\
(\%)\end{array}$ & $\begin{array}{c}\text { Non- } \\
\text { reducing } \\
\text { sugar }(\%)\end{array}$ & $\begin{array}{c}\text { Ascorbic } \\
\text { acid mg } \\
100 \mathrm{~g}^{-1}\end{array}$ \\
\hline $\mathrm{H}_{1} \mathrm{R}_{1}$ & 14.97 & 140.83 & 16.39 & 14.40 & 93.75 & 139.33 & 2.672 & 18.32 & 16.12 & 8.14 & 7.59 & 12.59 \\
\hline $\mathrm{H}_{1} \mathrm{R}_{2}$ & 14.87 & 139.25 & 16.37 & 14.38 & 92.52 & 139.33 & 2.654 & 18.25 & 16.23 & 8.23 & 7.60 & 12.37 \\
\hline $\mathrm{H}_{1} \mathrm{R}_{3}$ & 14.62 & 137.28 & 16.24 & 14.34 & 90.83 & 138.33 & 2.609 & 18.38 & 16.73 & 8.69 & 7.64 & 12.81 \\
\hline $\mathrm{H}_{1} \mathrm{R}_{4}$ & 12.37 & 127.70 & 15.04 & 14.31 & 79.29 & 141.00 & 2.208 & 18.35 & 16.45 & 8.70 & 7.36 & 12.23 \\
\hline $\mathrm{H}_{2} \mathrm{R}_{1}$ & 13.50 & 148.13 & 17.98 & 15.26 & 98.38 & 130.83 & 2.465 & 18.18 & 16.54 & 8.82 & 7.34 & 12.50 \\
\hline $\mathrm{H}_{2} \mathrm{R}_{2}$ & 13.13 & 141.38 & 17.89 & 14.70 & 93.09 & 132.17 & 2.398 & 18.28 & 16.64 & 8.96 & 7.29 & 12.57 \\
\hline $\mathrm{H}_{2} \mathrm{R}_{3}$ & 12.67 & 143.17 & 17.63 & 14.37 & 95.10 & 133.33 & 2.313 & 18.28 & 16.41 & 8.83 & 7.21 & 12.37 \\
\hline $\mathrm{H}_{2} \mathrm{R}_{4}$ & 12.02 & 130.35 & 15.08 & 14.29 & 86.71 & 135.00 & 2.194 & 18.15 & 16.71 & 8.96 & 7.37 & 12.48 \\
\hline $\mathrm{H}_{3} \mathrm{R}_{1}$ & 12.98 & 174.08 & 20.11 & 16.26 & 115.49 & 128.33 & 2.370 & 18.27 & 17.06 & 9.08 & 7.59 & 12.81 \\
\hline $\mathrm{H}_{3} \mathrm{R}_{2}$ & 12.68 & 173.43 & 19.21 & 16.00 & 115.26 & 129.33 & 2.316 & 18.35 & 16.96 & 9.03 & 7.54 & 12.71 \\
\hline $\mathrm{H}_{3} \mathrm{R}_{3}$ & 12.45 & 168.20 & 18.85 & 15.99 & 111.29 & 130.00 & 2.273 & 18.38 & 16.85 & 9.08 & 7.38 & 12.51 \\
\hline $\mathrm{H}_{3} \mathrm{R}_{4}$ & 11.23 & 154.57 & 17.92 & 15.90 & 102.29 & 131.67 & 2.051 & 18.32 & 16.98 & 8.98 & 7.60 & 12.55 \\
\hline $\mathrm{SEm} \pm$ & 0.901 & 3.054 & 0.532 & 0.184 & 2.155 & 3.918 & 0.164 & 0.155 & 0.331 & 0.175 & 0.247 & 1.163 \\
\hline $\mathrm{CD}^{\#}$ & 2.630 & 8.914 & 1.553 & 0.537 & 6.290 & 11.436 & 0.479 & NS & NS & NS & NS & NS \\
\hline Control & 15.03 & 110.23 & 14.95 & 14.28 & 72.82 & 146.33 & 2.440 & 17.93 & 16.46 & 8.36 & 7.70 & 12.42 \\
\hline \multicolumn{13}{|c|}{ Control vs. Rest } \\
\hline $\operatorname{SEm} \pm$ & 1.786 & 6.096 & 1.052 & 0.364 & 4.279 & 7.768 & 0.324 & 0.305 & 0.653 & 0.345 & 0.485 & 2.286 \\
\hline $\mathrm{CD}^{\#}$ & 3.686 & 7.393 & 2.171 & 0.751 & 9.180 & 16.032 & NS & NS & NS & 0.712 & NS & NS \\
\hline
\end{tabular}

${ }^{\#} \mathrm{CD}$ at $p=0.05 ;{ }^{*} \mathrm{NS}$ : Non significant

positively as expressed by principal component analysis 1 (Factor-1) and factor 1 explained over 55\% of total variance. Similarly factor 2 explaining further $20 \%$ of total variance was dominated by positively loaded characters like bunch weight, harvest index, benefit-cost ratio and non reducing sugar (Figure 1). From the scatter diagram of regression factor scores for Factor-1 vs Factor-2, it was concluded that removal of three hands immediately after opening of last hand $\left(H_{3} R_{1}\right)$ followed by removal of three hands after one week of opening of last hand $\left(\mathrm{H}_{3} \mathrm{R}_{2}\right)$ and removal of three hands after two weeks of opening of last hand $\left(\mathrm{H}_{3} \mathrm{R}_{3}\right)$ were influential treatment combinations for characters representing factor 1 . But second factor was headed by $\mathrm{H}_{1} \mathrm{R}_{1}, \mathrm{H}_{1} \mathrm{R}_{3}, \mathrm{H}_{1} \mathrm{R}_{2}, \mathrm{H}_{3} \mathrm{R}_{2}$ and $\mathrm{H}_{3} \mathrm{R}_{1}$ of which $\mathrm{H}_{3} \mathrm{R}_{2}$ and $\mathrm{H}_{3} \mathrm{R}_{1}$ are common to factor 1 . So, considering both factors the promising treatment combination were removal of three hands after one week of opening of last hand $\left(\mathrm{H}_{3} \mathrm{R}_{2}\right)$ and removal of three hands immediately after opening of last hand $\left(\mathrm{H}_{3} \mathrm{R}_{1}\right)$.

Factor 3 was dominated by non-reducing sugar with highest positive loading in contrast to total soluble solids. Factor 3 explained about $9 \%$ of total variance and the respective positively loaded treatment was the untrimmed bunches (control). Removal of three and two hands after three weeks of opening of last hand $\left(\mathrm{H}_{3} \mathrm{R}_{4}\right.$ and $\left.\mathrm{H}_{2} \mathrm{R}_{4}\right)$ and removal of three hands immediately and one week after opening of last hand $\left(\mathrm{H}_{3} \mathrm{R}_{1}\right.$ and $\left.\mathrm{H}_{3} \mathrm{R}_{2}\right)$ were found most performing treatment

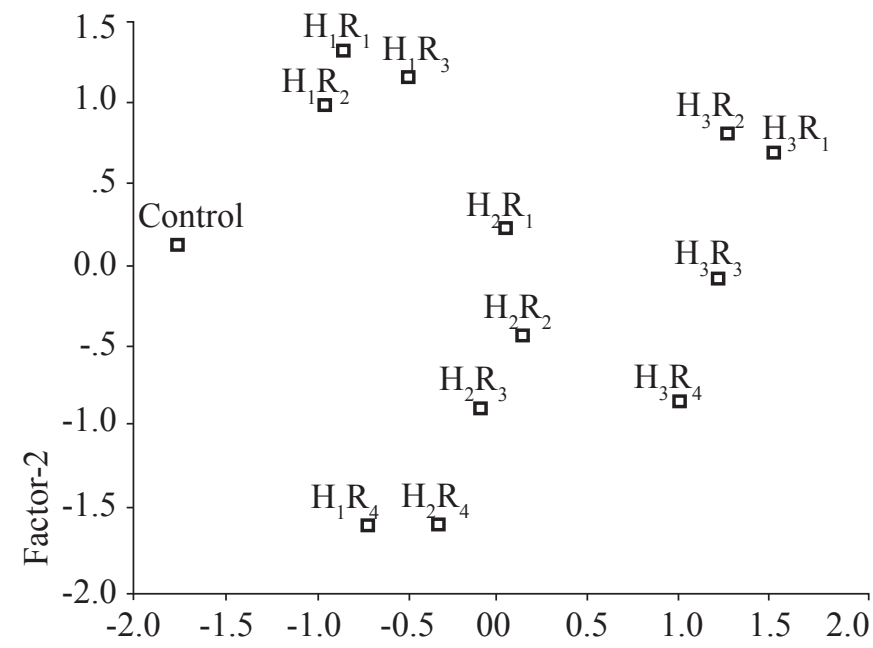

Factor-1

Figure 1: Scatter diagram of regression factor scores for Factor-1 vs. Factor-2

combinations (Figure 2). However, considering along with factor 1 the best combinations are removal of three hands immediately after opening of last hand $\left(\mathrm{H}_{3} \mathrm{R}_{1}\right)$ followed by removal of three hands after one week of opening of last hand $\left(\mathrm{H}_{3} \mathrm{R}_{2}\right)$ and removal of three hands after three weeks of opening of last hand $\left(\mathrm{H}_{3} \mathrm{R}_{4}\right)$. Lastly factor 4 explained approximately $8 \%$ of total variance and the treatment of negatively loaded character of total soluble solids represented by removal of 
one hand after three weeks of opening of last hand $\left(\mathrm{H}_{1} \mathrm{R}_{4}\right)$ and removal of three hands after one week of opening of last hand $\left(\mathrm{H}_{3} \mathrm{R}_{2}\right)$ were governing treatments (Figure 3 ). However, our screening of best treatment combinations if confined to the results of first three factors, the desirable treatment combinations would be removal of three hands immediately after opening of last hand $\left(\mathrm{H}_{3} \mathrm{R}_{1}\right)$ and removal of three hands after one week of opening of last hand $\left(\mathrm{H}_{3} \mathrm{R}_{2}\right)$.

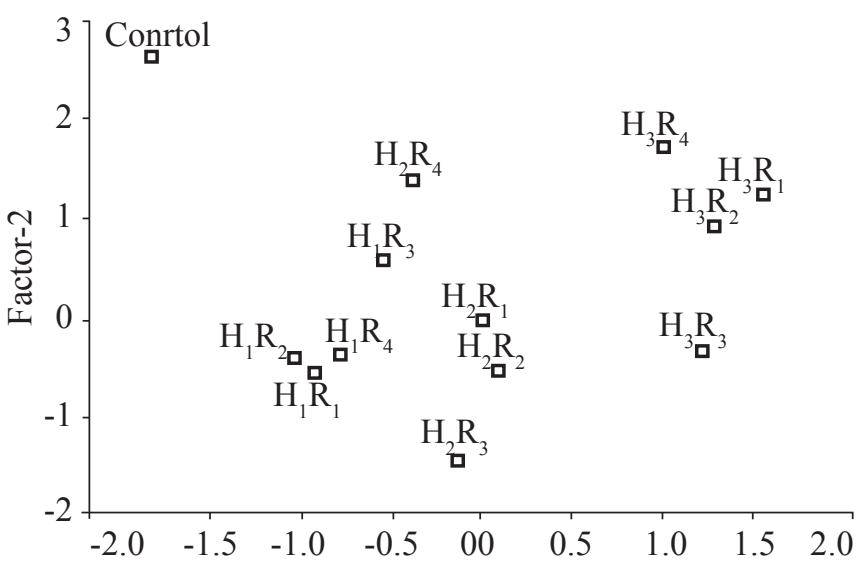

Factor-1

Figure 2: Scatter diagram of regression factor scores for Factor-1 vs. Factor-3

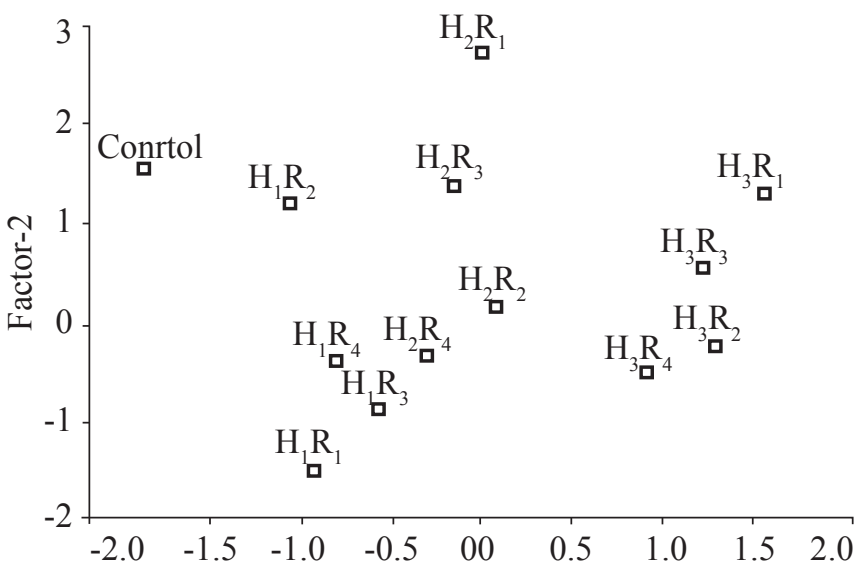

Factor-1

Figure 3: Scatter diagram of regression factor scores for Factor-1 vs. Factor-4

\section{Conclusion}

Removal of three hands within one week of opening of last hand would be beneficial for improving finger size and quality of banana which in turn may meet the demand of super as well as export market.

\section{References}

Aba, S.C., Baiyeri, K.P., Tenkouano, A., 2009. Factorial combination of manure rates and bunch pruning intensities influenced bunch physical traits of two plantain (Musa spp. ABB) genotypes. International Agrophysics 23, 207-213.

Baiyeri, K.P., Aba, S.C., Faturoti, B.O., Tenkouano, A., 2009. Effects of poultry manure and bunch pruning management on fruit size, shelf life and pulp colour of 'PITA24' and 'Mbi-Egome' plantains (Musa sp. AAB group). Journal of Animal and Plant Sciences 3, 215-226.

Baiyeri, K.P., Aba, S.C., Tenkouano, A., 2010. Trimming of bunch pruning enhances bunch and fruit qualities of 'PITA24' plantain (Musa AAB) hybrid. Journal of Applied Bioscience 33, 2110-2118.

Dennis, F. G., 1982. Fruit development. in: Tesar, M.B.(Ed.), Physiological Basis of Crop Growth and development. American Society of Agronomy, Medison, USA.

Gottreich, M., Brada, D., Walevay, V., 1964. A sample method for determining banana fruit weights. Kravim 14, 161-162.

Huda, S., Victor Sadras, Wani, S.P., and Mei, Xurong. 2011. Food Security and Climate Change in the AsiaPacific Region: Evaluating Mismatch between Crop Development and Water Availability. International Journal for Bio-resource and Stress Management 2 (2), 137-144.

Jullien, A., Malezieux, E., Michaux-Ferriere, N., Chillet, M., Ney, B., 2001a. Within-bunch variability in banana fruit weight: Importance of developmental lag between fruits. Annals of Botany 87, 101-108.

Jullien, A., Munier-Jolian, N.G., Malezieux, E., Chillet, M., Ney, B., 2001b. Effect of pulp cell number and assimilate availability on dry matter accumulation rate in a banana fruit [Musa sp. AAA group 'Grande Naine' (Cavendish sub group)]. Annals of Botany 88, 321-330.

Krauss, U., Figueroa, R. Johanson, A., Sreralo, E., Anguiz, R., Cabezas, O., Garcia, A., 1999. Musa clones in Peru: classification, uses, production potential and constraints. Infomusa 8, 19-26.

Kurien, S., Anil, B.K., Rajeevan, P.K., Bharathan, V., Krishnan, S., 2000. Phosphorus mobilization to uneconomic tissues and effect of bunch trimming regimes in banana. Scientia Horticulture 83, 25-32.

Quintero, J.A.S., Aristizabal, M.L., 2003. Effects of dehanding on the production characteristics of plantain 'Dominico Harton' and 'Africa' in Colombia. Infomusa 12, 44-46.

Rodriguez, J.A., Irizarry, H., Rivera, E., 1988. Effect of bunch trimming on yield and quality of plantains (M. acuminate XM. balbisiana, AAB). in: Jaramillo, R., Restrepo, A. and Bayona, R. (Editors). Acorbat,Medellin, Colombia, 537-541.

Wanichkul, K., Boonma, S., 2009. Influence of hand thinning on yield and fruit quality of banana [Musa (AAB group) 'Kluai Namwa Kom']. Agricultural Science Journal 40, 185-188.

Weerasinghe, S.S., Ruwanpathirana, K.H., 2004. Effect of dehanding on bunch characteristics of banana. Annals of Sri Lanka Department of Agriculture 6, 227-235. 